\title{
Mensagem da Presidente da S.P.Q.
}

DIRECÇÃO DA S.P.Q.

Presidente - M. Alzira Amoster Ferreira

Vice-Presidente - Manuel A. V. Ribeiro da Silva

Secretário Geral - A. Romão Dias

Secretário Geral Adjunto - M. Nunes da Ponte

Tesoureiro - Francisco Pedroso

Secretário Adjunto - M. Cândida Vaz

Conselho Fiscal

Presidente - César Viana

Vice-Presidente - Luis Alcácer

Relator - V. Meira Soares

Mesa da Assembleia Geral

Presidente - B. Herold

1. ${ }^{\circ}$ Secretário - Alberto Amaral

2. ${ }^{\circ}$ Secretário - Teixeira Dias

Assembleias Regionais

DELEGADO DO NORTE (Sede no Porto)

Assembleia Regional

Presidente - João Luis Cabreira de Oliveira Cabral 1. ${ }^{\circ}$ Secretário - José Luis C. Conceiçăo Figueiredo $2 .^{\circ}$ Secretário - Rui Adelino Torcato Barroca

\section{Direcção da Delegação Regional}

Presidente - Manuel Anibal V. Ribeiro da Silva Secretário - José Alberto Nunes Ferreira Gomes Vogal - José Luis Fontes da Costa Lima

\section{DELEGAÇÃO DO CENTRO (Sede em Coimbra)}

\section{Assembleia Regional}

Presidente - António J. Campos Varandas

1. ${ }^{\circ}$ Secretário - Júlio António Marques da Cunha Pin. to

2. ${ }^{\circ}$ Secretário - Maria Helena Ferreira Teixeira

\section{Direcçăo da Delegação Regional}

Presidente - António José Ferrer Correia Secretário - Maria da Conceição Pedroso Lima Vogal - Maria Isabel Almeida Ferra

DELEGAÇĀO DO SUL (Sede em Lisboa)

\section{Assembleia Regional}

Presidente - José Luis Cardoso Pereira $1 .^{\circ}$ Secretário - José Dias Lopes da Silva 2. ${ }^{\circ}$ Secretário - Carlos José Rodrigues Crispim Romão

\section{Direcção da Delegação Regional}

Presidente - Maria Alzira Almoster Ferreira Secretário - José Miguel da Costa Reis Vogal - Maria Isabel da Silva Martinho Simōes Execução gráfica - Proença, Coop. de Artes Gráficas, SCARL. Tel. 869249
M. Alzira Almoster
Ferreira
Presidente da S.P.Q.

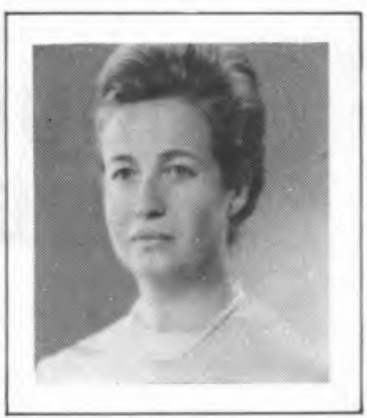

Mais um ano se inicia na vida da Sociedade Portuguesa de Quimica que esperamos constitua um novo avanço no esforço de renovação e desenvolvimento das suas potencialidades.

Participar na vida da S.PQ. como membro dos seus corpos directivos tem constituido uma oportunidade excepcional para, em conjunto com outros, meditar sobre as relações entre a quimica e as actividades dos químicos e os anseios e receios da humanidade.

A variedade de assuntos que dizem respeito à química e a relevância dos mesmos nas necessidades económicas e humanas actuais são significativas da importância da química como ciência, e das suas aplicações. Muito poderá fazer-se através dos progressos da química, para ajudar a resolver problemas de energia, recursos naturais, agricultura, saúde e tantos outros de menor vulto mas nem por isso menos importantes. Compete-nos, por isso, procurar os meios mais eficazes de fazer avançar e utilizar os nossos conhecimentos em quimica e promover o seu intercâmbio internacional, do que poderá resultar uma mais rápida melhoria da condição humana.

Uma conclusão consoladora a que facilmente se chega é que as pessoas não são intrinsecamente contra a ciência ou a tecnologia. O que as preocupa é como e quem decide nesses dominios, desejando, naturalmente, que não sejam postos em causa o futuro e o bem estar da humanidade.

Os químicos podem e devem estar envolvidos em numerosas decisões a tomar, quer como cientistas, quer como simples cidadãos que todos são.

Como cientistas, alguns estarão empenhados na expansão do conhecimento científico, outros no desenvolvimento de novas opções tecnológicas, outros ainda em fazer compreender a necessidade e oportunidade dessas mesmas opções. Todos, como cidadãos, têm obrigação de informar, e talvez influenciar, a opinião pública no âmbito que têm o privilégio de melhor conhecer.

Atravessamos uma época de profundas transformações em que um papel importante está reservado a todos os que profissionalmente estão envolvidos na ciência e na tecnologia. Que cada um de nós contribua com a sua quota parte, seja ela maior ou menor, em espírito de cooperação construtiva. 